Fikrah: Jurnal Ilmu Aqidah dan Studi Keagamaan

ISSN 2354-6147 EISSN 2476-9649

Tersedia online di: journal.stainkudus.ac.id/index.php/fikrah

DOI: 10.21043/fikrah.v5i1.2657

\title{
Demokrasi antara Pembatasan dan Kebebasan Beragama serta Implikasinya terhadap Formalisasi Islam
}

\author{
Abu Hapsin \\ UIN Walisongo, Semarang, Indonesia \\ abu_hapsin@walisongo.ac.id
}

\begin{abstract}
Abstrak
Tulisan ini membahas hubungan antara demokrasi dan kebebasan beragama. Jika demokrasi diartikan sebagai kebebasan berperilaku selama masih dalam frame konstitusional, maka permasalahannya ialah apakah boleh memaknai demokrasi dengan melakukan formalisasi agama dalam tatanan politik dan hukum dari suatu negara demokrasi? Pertanyaan tersebut bersandar pada anggapan bahwa agama tidak mempunyai ranah rasional, sehingga hubungan demokrasi dan kebebsan agama terkadang menjadi problematik ketika dipaksakan pada ranah konstitusional. Teori John Rawls dan Franklin I. Gamwell sebagai pemikir modern, menghasilakan simpulan bahwa pada wilayah tertentu agama tidak bisa dipaksakan masuk ranah politik, tetapi secara universal agama bagian dari politik.
\end{abstract}

Kata kunci: demokrasi, paradoksal, agama, kebebasan 


\begin{abstract}
This paper discusses the relationship between democracy and freedom of religion. If democracy is defined as the freedom to behave as long as it is still in the constitutional frame, then the problem is whether to interpret democracy by formalizing religion in the political and legal order of a democratic country? The question rests on the assumption that religion has no rational domain so that the relationship between democracy and religious freedom sometimes becomes problematic when imposed on the constitutional domain. Theories of John Rawls and Franklin I. Gamwell as modern thinkers led to the conclusion that in certain areas religion cannot be forced into the political sphere, but universally religion is part of politics.
\end{abstract}

Kata kunci: Democracy, paradox, religion, freedom

\title{
Pendahuluan
}

Dewasa ini, demokrasi menjadi kajian menarik ketika dihubungkan dengan agama. Terma demokrasi menjadi perbincangan hangat dari berbagai elemen masyarakat, seperti kalangan politisi dan akademisi profesional, serta orang-orang jalanan juga banyak membicarakan. Tetapi pada wilayah yang sama, demokrasi seringkali diartikan sebagai alat pembenar dari setiap tindakan, seperti kebebasan berpendapat ataupun berkeyakinan, namun tidak jarang berujung pada tindakan anarkis. Oleh sebab itu, demokrasi bersifat paradoksal dan mempunyai dua wajah yang tidak bisa dilepaskan satu sama lainnya, karena pada saat bersamaan demokrasi dijadikan justifikasi tindakan.

Memahami demokrasi sebagai kebebasan berdampak pada pertarungan identitas agama pada ranah politik, dimana setiap pemeluk agama akan berusaha memformalisasikan ajaran agama dalam wilayah publik (Audi \& Wolterstorff, 1977). Dalam hal ini, terdapat pertarungan ideologi agama-apakah terkait dengan dogma agama atau tafsir agama dari masing-masing pemeluk keyakinan dan kelompok interpretasi. Meskipun cara yang ditempuh melalui jalan konstitusional, tetapi menimbulkan pertanyaan penting, yaitu apakah memaknai demokrasi dengan cara formalisasi agama dapat dibenarkan? Pada dasarnya negara mempunyai kewajiban memenuhi kebutuhan warganya dalam menjalankan ritual agama (Mclver, 1950). Dengan demikian, pelembagaan ajaran agama sebagai tanggung jawab formal dari negara atas terjaminnya keberlangsungan ajaran agama. Hal ini harus dipenuhi dalam 
wilayah welfare state, sehingga agama bisa menjadi bagian dari undang-undang kehidupan berbangsa (Haryatmoko, 1998). Meski demikian, tidak berarti agama mempunyai peran penuh dalam kehiduapn bernegara, karena keterjaminan ajaran agama bukan agama itu sendiri, tetapi lebih pada nilai agama yang harus diaplikasikan sebagai atuaran beragama dalam negara.

Perdebatan tentang agama dan demokrasi menjadi bagian penting, karena secara ontologi keduanya merupakan komponen yang berbeda dan tidak mempunyai hubungan secara epsitemologis. Hal ini diperparah dengan sebuah tesis yang menyatakan bahwa agama bersifat transendental dan tidak bisa dirasio, hanya bisa diamalkan. Pada wilayah yang sama, demokrasi adalah putusan politik yang bersumber dari kesepatakan manusia untuk mencari strategi terbaik dalam membangun negara. Tetapi dalam tatanan sosial-politik, agama tidak bisa memberikan jawaban atas problematika umat melalui kebijakan publik yang lahir dari putusan politik. Sehingga untuk menjawab hal tersebut agama harus hadir dengan nilai-nilai yang bisa disepakati bersama antar pemeluk agama di parlemen. Adapun formalisasik agama harus bersandar pada paradigma etik-subtantif atau moral ideal yang sejalan dengan prinsip demokrasi. Dalam hal ini, terdapat negosiasi makna dan nilai dari agama, yaitu hadirnya agama dalam kehidupan manusia yang dilingkupi problematika kehidupan. Tetapi batasan mutlak dari negosiasi ialah interpretasi agama tidak boleh dimiliki oleh sebagian orang dan organisasi keagamaan, karen harus berdasarkan pada keadilan sosial.

\section{Batasan Kebebasan Beragama}

Dalam bahasa Inggris, kebebasan beragama diistilahkan dalam dua pengertian yakni "religious freedom" dan "religious liberty ". Kedua istilah ini sering digunakan secara bergantian yang bermakna kebebasan dalam mengekspresikan berpikir dari pemahaman yang diyakini. Namun dalam konteks politik dan hukum, istilah "religious freedom" lebih sering digunakan daripada "religious liberty. Terma tersebut didasarkan pada kebebasan manusia secara fundamental yang bersifat ketuhanan, dimana manusia mempunyai kebebasan dalam mengekpresikan keyakinannya. 
Menurut Carillo de Albornoz sebagaimana dikutip dalam Koshy (1992) berpendapat bahwa religious liberty atau kebebasan beragama memiliki empat aspek utama yakni: kebebasan nurani (liberty of conscience), kebebasan mengekspresikan pemaham keagamaan (liberty of religious expression), kebebasan melakukan perkumpulan keagamaan (liberty of religious association), dan kebebasan melembagakan keagamaan (liberty of religious institutionalization). Diantara keempat aspek tersebut, aspek pertama merupakan hak yang paling asli dan absolut dalam artian tidak terpisah dari diri manusia. Oleh sebab itu, konsep kebebasan beragama bisa mencakup kebebasan untuk memilih atau tidak memilih agama tertentu. Pengertian ini menandakan bahwa, manusia mempunyai kebebasan beragama ataupun tidak beragama yang didasarkan pada eksistensinya sendiri, karena manusia adalah makluk bebas yang didasarkan pada logikanya.

Konsekuensi dari makna tersebut ialah kebenaran pribadi harus dianggap sebagai sebuah nilai yang paling luhur dan agung (supreme value), karena menghendaki sebuah komitmen dan tanggung jawab pribadi yang mendalam. Dengan bahasa sederhana, manusia mempunyai keluhuran secara individual, yaitu kebebasan dalam menentukan pilihan dan sikap harus berada di atas segalanya, termasuk harus bebas dari agen-agen otoritatif lainnya seperti pemerintah, masyarakat dan bahkan Tuhan. Pada konteks ini manusia didefinisikan sebagai makhluk yang utuh yang memiliki kebebasan dalam menentukan dirinya sendiri berdasarkan keyakinan hati nuraninya (Gamwell, 1995). Pengertian ini mengembalikan manusia pada jati dirinya sebagai ciptaan Tuhan yang mempunyai kebebasan dalam menjalankan kehidupannya.

Manusia mempunyai dua dimensi, yaitu dimensi internal dan eksternal. Kebebasan nurani merupakan dimensi internal dari konsep kebebasan beragama. Sedangkan manifestasi dari kesadaran nurani merupakan dimensi eksternal, yang diwujudkan secara personal, sosial dan institusional. Oleh sebab itu, definisi kebebasan beragama juga mencakup dimensi eksternal dari kebebasan nurani (liberty of conscience). Dua dimensi tersebut saling berhubungan dan mempunyai konsekuensi pada kehidupannya sendiri maupun sosial. Hal ini didasarkan atas logika bahwa sebuah agama hanya bisa disebut sebagai agama jika sudah berwujud institusi sosial, karena secara sosiologi agama yang bersifat indiviual tidak bisa disebut agama. Dalam hal ini, 
agama dimaknai sebagai dimensi sosial, yaitu mempunyai pengaruh dan diinstitusikan dalam ruang-ruang sosial. Dengan demikian kebebasan beragama tidak hanya bersifat individual, tetapi mencakup kebebasan untuk menginstitusionalisasikan ajaran agama serta kebebasan untuk melakukan asosiasi keagamaan (El. Wa, 1983). Pada wilayah ini agama dipahami sebagai ajaran yang mengikat yang dapat diinstitusikan di ranah sosial supaya dapat dihayati oleh masing-masing pemeluknya. Tetapi menginstitusikan agama tidak bisa tanpa adanya musyawarah mufakat dari elemen masyarakat.

Terdapat perbedaan antara dimensi internal dan eksternal, dimensi eksternal bersifat relatif-kondisional dan berkaitan dengan realitas soaial. Dengan bahasa yang mudah ialah dalam rangka mewujudkan kebebasan nurani harus bergantung pada agen-agen otoritatif lain yang mengatur berkehidupan dalam berkeyakinan seperti pemerintah dan elemen-elemen pengambil kebijakan. Meskipun keyakinan atau kesadaran pribadi meyakini bahwa melakukan tindakan bunuh diri adalah suatu perbuatan mulia, seseorang tidak mempunyai kebebasan untuk mewujudkannya dengan alasan hak asasi, karena mengabaikan pandangan otoritas lainnya, seperti masyarakat atau pemerintah. Manifestasi dari kebebasan beragama menjadi hak publik dalam memberikan penilaian. Dalam hal ini, publik menjadi hakim dari setiap tindakan eksternal seorang, karena dimensi eksternal tidak bisa lepas dari persepsi masyarakat dan pemerintah. Dengan demikian masyarakat umum memiliki hak untuk melakukan penilaian terhadap sebuah pemahaman agama pada saat masuk arena politik. Dalam konteks inilah konsep kebebasan beragama sangat terkait erat dengan perubahan politik.

\section{Metode Penelitian}

Tulisan ini menggunakan metode kualitatif yang mengkaji objek secara alamiah, dimana dalam hal ini peneliti menjadi istrumen kunci (Moleong, 1989, hal. 2). Adapun model penelitian bersifat kepustakaan (Library Research) yang mengkaji gagasan dari seseorang atau bersifat teoritis dengan penekanan atas data yang bersifat literatur yang mempunyai relevansi dari objek yang dikaji (Hadi, 1983, hal. 9). Penggalian data bisa berbentuk tulisan, gambar atau karya monumental seseorang yang dapat ditelusuri terkait dengan tema yang sedang dikaji (Sugiyono, 2005, hal. 52). 
Penulis menggunakan analisis data secara induktif. Hal in disebabkan kajian yang dilakukan berbentuk kualitatif yang menafsirkan dari sejumlah yang bersifat khusus untuk ditarik pada simpulan yang bersifat umum (Anwar, 1998, hal. 40).

Tulisan ini menggunakan dua teori sebagai alat analisa. Pertama, Kelompok sparationist atau privatist yang diwakili oleh John Rawls yang menyatakan bahwa agama sebagai dogma adalah institusi terpisah dari persoalan politik atau kenegaraan, karana agama hanya dianggap sebagai ritual dari Tuhan yang berkaitan persoalan individu dan tidak bisa diaplikasikan dalam ranah pemerintahan. Gagasan tersebut ditawarkan oleh Rawls sebagai filosof yang beraliran liberal dan mempunyai pengaruh di Harvard University, Amerika. Kedua, diwakili Franklin I. Gamwell, seorang guru besar di bidang religious studies di University of Chicago. Kelompok ini berangkat dari tesis bahwa setiap perilaku manusia yang berkait dengan keagamaan maupun kenegaraan adalah bagian yang saling terkait, sehingga menyatakan bahwa agama menjadi bagian dari politik. Hal ini menandakan bahwa agama tidak ditafsirkan sebagai dogma transendental yang bersifat absolut, tetapi lebih pada mengambil nilai historis dan keluhuran agama yang dapat di satukan dengan paham kenegaranaan. Adapun dalam mengatur kepentingan paham keagaman harus melalui jalan demokrasi yang bertumpu pada keadilan prosedural. Dalam hal ini, demokrasi digunakan sebagai mekanisme dalam mengatur relasi agama dan negara dan keadilan yang menjadi pertimbangan utama.

\section{Demokrasi dan Kebebasan Beragama}

Dewasa ini, agama menjadi bagian dari problematika politik modern yang banyak menyita perhatian dari berbagai kalangan dalam mencarikan solusi. Problematika politik modern merujuk pada suatu kondisi dimana terjadi klaim otoritas agama sebagai dasar politik dari dari kelompok keagamaan. Dengan kata lain, otoritas agama tertentu mengklaim telah mendapatkan mandat untuk menjadikan dogma agama sebagai asas berpolitik. Adanya kelompok kegamaan yang variatif di dunia politik tidak jarang menjadi prolem baru dalam putusan politik, tetapi otoritas koersif dari paham keagamaan menjadi pembeda dalam menentukan identitas, yaitu memilih jalan kepakarannya dalam memberikan pengaruh. Namun, tidak bijaksana 
menggunakan identitas agama dalam ruang lingkup negara demokratis, karena otoritas agama tidak menjadi prioritas penuh dalam putusan politik, tetapi lebih menjadi bagian tertentu. Oleh karena itu, harus ada upaya-upaya yang mampu menyatukan gagasan demokrasi di satu sisi dan konsep kebebasan beragama pada sisi lain (Gray, 1991). Sehingga tidak terjadi tumpang tindih dalam pengaplikasian keduanya dalam ranah publik, dan tidak terjadi salah paham dalam memaknainya.

Gagasan tentang penyatuan agama dan politik tidak akan menemukan jalan sama, dan keduanya memang cenderung harus berbeda. Pemikiran ini diprakarsai golongan sparationist yang menempatkan agama sebagai urusan individu bukan merupakan urusan negara. Dengan demikian, kalangan sparationist yang dikenal dengan sebutan privatist karena kecenderungannya yang kuat untuk menempatkan agama menjadi urusan pribadi. Argumentasi tersebut dikonstuksi dari asumsi bahwa agama tidak dapat dirasional dan tidak layak dibawa ke arena politik. Konsekuensi logisnya ialah berdampak pada hampanya upaya dalam menyatukan agama dan politik dalam pemerintahan, karena epistemologi keduanya berbeda dan satu sama lainnya tidak mempunyai akar sama dalam kehidupan manusia. Namun keduanya dapat dinarasikan dengan dua hal sebagai suatu yang berbeda, yaitu memandang agama sebagai suatu institusi sosial yang harus terpisah dari institusi politik (sparationist), karena agama dan politik disinyalir dua institusi memiliki wilayah berbeda, sehingga bidang yang dikaji berlainan. Oleh sebab itu, dalam konteks ini harus terdapat pembatas yang jelas agar tidak terjadi benturan kepentingan antara keduanya.

Agama yang memiliki ajaran komprehensif tidak bisa dipisahkan dari kehidupan manusia, termasuk dalam kehidupan bernegara dan berpolitik. Oleh sebab itu, agama tidak bisa hanya dinilai sebagai konstitusi spiritual, tetpai harus menjadi media sosial yang memainkan perannya dalam ranah politik, yaitu merepresentasikan perilaku keagamaan dengan ajaran dan nilai yang sudah ditransformasikan menjadi nilai-nilai budaya politik tanpa membedakan latar belakang keyakinan yang dianut oleh masyarakat. Inilah yang dimaksud dengan istilah overlapping consensus (John Rawls, 1993), sebuah istilah yang secara konotatif mengesampingkan peran agama secara keseluruhan untuk dijadikan dasar pijakan berpolitik. Agama menjadi bagian politik, bukan memaknai politik dalam artian pragmatis, tetapi artian idealis atau rasionalis 
yang menjadikan politik sebagai media untuk menuju kemakmuran dengan niali-nilai luhur agama. Dengan demikian, pada wilayah sosial agama harus mampu hadis sebagai sosusi atas problem kemanusiaa yang dilakukan dengan jalan politis, yaitu ikut serta atau mengawasi putusan-putusan politik yang berkaitan dengan hajat orang banyak yang diambil dari ajaran-ajaran agama yang bersifat luhur.

Konsep overlapping consensus berarti sebuah kesepakatan bersama warga masyarakat dari berbagai latar belakang keyakinan untuk menjadikan kesamaankesamaan visi politik mereka sebagai platform politik, sehingga semua masyarakat dapat berperan bersama. Prinsip ini didasarkan atas satu asumsi bahwa pada dasarnya masyarakat merupakan sebuah sistem yang berkemampuan untuk melakukan kerja sama yang baik (John Rawls, 1993). Setiap masyarakat yang terlibat harus diberikan kebebasan serta hak yang sama. Namun satu hal yang menjadi prinsip bahwa setiap gagasan yang dikemukakan hendaknya tidak dikemas dalam bentuk doktrinal. Gagasangasan politik harus diupayakan agar netral dari doktrin agama. Inilah yang oleh Rawls (John Rawls, 1993) diistilahkan dengan freestanding view. Sehingga agama tidak dapat menjadi pemisah terhadap kelompok politik yang mengabdikan dirinya dalam negara, karena manusia yang menjadi bagian dari kelompok ini telah melepaskan agama sebagian doktri, dan tidak sebagai nalar.

Pada satu sisi gagasan liberalisme politik John Rawls mampu meredam konflik politik horizontal, yaitu menempatkan agama sebagai urusan pribadi, dan tidak menjadi urusan negara. Sehingga negara tidak mempunyai kepentingan untuk mengurus dan mengatur ajaran-ajaran agama yang terkadang memicu persengketaan antar agama. Namun satu kelemahannya ialah Rawls telah membawa manusia pada keadaan split personality, yaitu kecendrungan untuk tidak menjadi manusia ganda. Karena sebagai manusia politik, seseorang tidak dapat menampilkan diri sebagai manusia yang utuh. Sehingga seseorang harus melepas peran agama dalam mewujudkan gagasan-gagasan politiknya demi terealisasi prinsip overlapping consensus. Oleh karena itu liberalisme politik yang dikembangkan merupakan sebuah paradok (Gray, 1993). Gagasan Rawls yang berkaitan dengan kebebasan beragama terkesan tidak konsisten dalam mempertahankan gagasannya, sehingga diragukan efektifitasnya dalam menjawab problematika politik modern. 
Menurut Franklin I. Gamwell (1995) untuk mengatasi problematika politik modern ialah harus memahamai bahwa kebebasan beragama dan demokrasi merupakan dua prinsip yang dapat berjalan paralel. Namun hal ini tidak akan berjalan dengan baik ketika agama diyakini sebagai sesuatu yang tidak rasional. Karena merubah paradigma agama dari tidak rasional menjadi rasional merupakan prasyarat untuk mendialogkan agama dan politik. Dengan demikian, setiap keyakinan dapat menjadi bagian dari politik. Dalam wacana demokratik, tidak ada larangan dan batasan bagi seorang untuk menyampaikan paham keagamaannya. Sikap diskriminatif dapat mencederai demokrasi dan kebebasan berpendapat. Karena setiap warga negara mempunyai hak dalam mengaspirasikan paham keagamaanya dalam ruang lingkup demokrasi.

Kebebasan berekspresi dalam konteks warga negara perspektif Paul M. Johnson yang dikutip oleh Kholiludin (2009) disebut sebagai civil rights and civil liberties diartikan sebagai hak tiap warga negara dalam kaitannya dengan kebebasan untuk berpikir, bergerak, berekspresi dan kebebasan individual untuk membentuk ortanisasi secara serta mengejar tujuan umum, dan kebebasan untuk mengambil bagian secara politik dalam cara yang tidak melanggar hak orang lain. Gagasan ini menyadari adanya kebebasan manusia secara naluri dalam mengekspresikan pemikiran, perilaku dalam rangka membangun negara. Sehingga setiap paham keagamaan merupakan kemurnian naluri dari manusia yang diharus diakui sebagai kesucian.

Paham keagamaan merupakan refleksi dari hasil pemahaman komprehensif (comprehensive understanding) seorang atas ajaran agama dan problem sosial. Dengan demikian pemahaman tersebut merupakan representasi dari interaksi pemahaman seorang atas ajaran agama dan problem sosial, sehingga diaplikasikan dalam bentuk tindakan baik yang dilakukan secara sadar maupun tidak. Atas dasar ini, setiap pemahaman manusia atas alam sekitarnya tidak selalu mewakili alam itu sendiri atau bersifat eksplisit, karena pemahaman adalah usaha dalam memahami objeknya yang terkadang melapaui objek itu sendiri. Banyak hal yang dipilih atau dilakukan manusia tanpa sadar dan hanya bersifat implisit. Namun, pada wilayah tertentu pemahaman implisit cukup determinan dan mempengaruhi sehingga menentukan pola pikir dan tindakan manusia (Gamwell, 1995). 
Perilaku manusia ditentukan oleh pemahamannya sendiri. Dengan bahasa sederhana, pemahaman manusia atau sejarah kehidupan manusia (historical logic) mempunyai pengaruh yang kuat dalam kehidupannya, atau dalam memahamai ajaran agama. Salah satau cara untuk membedakan perilaku tersebut-apakah bagian politik atau agama-seorang harus memahami tindakannya atau putusan secara eksplisit (Greevawalt, 1988), seperti ketika negara menetapkan sebuah peraturan perundangan yang menghukum pengedar dan pengkonsumsi minuman keras. Kebijkan tersebut diambil sebagai bentuk tanggungjawab negara pada warganya dalam wilayah politik. Tetapi umat Islam boleh mengklaim bahwa aturan tersebut merupakan kegiatan keagamaan, sebab negara mendukung teraplikasinya ajaran agama dalam kehidupan sosial. Diambilnya keputusan tentang pelarangan tersebut tidak bisa lepas dari dialog interaktif pengambil keputusan sebagai pemeluk agama dan sebagai pemerintah, sehingga kecenderungan atas pelarangan tidak bisa lepas atas nilai keagamaan.

Klaim masyarakat agama tertentu atas kebijakan politik bukan berarti menafikan peranan agama lain, tetapi dalam hal ini Gamwell ingin menyampaikan bahwa masyarakat agama lebih meyakini ajaran agama dibanding putusan politik, karena dalam kehidupan sosial, agama adalah bentuk kebudayaan primer. Adapun kebijakan politik yang memuat ajaran agama didefinisikan sebagai bentuk asosiasi. Oleh sebab itu, agama lebih memainkan peranannya dalam kehidupan masyarakat agama dibandingkan putusan politik atau kebijakan negara. Karena agama mempunyai nilai universal yang dapat berlaku sepanjang kehidupan manusia, dengan alasan tersebut agama harus eksis dan berperan dalam penentuan kebijakan negara (Gamwell, 1995). Konsekuensinya ialah agama harus siap diperdebatkan di wilayah publik (Haynes, 1993). Dalam konteks ini, ajaran agama akan diuji di dunia publik, karena agama sudah melepaskan dirinya dari sifat transendental dan merubah nilainya menjadi bagian dari kehidupan publik.

Gamwell meyakini setiap agama dapat direpresentasikan dalam wilayah politik, dan setiap ajaran bisa ditransformasikan atau bahkan diadopsi menjadi kebijaksanaan negara. Hal ini bertujuan supaya terdapat relasi interaktif antara agama dan negara, dan agama tidak hanya menjadi ajaran yang langit, tetapi dapat diterapkan dalam kehidupan sosial. Konsekuensi logis dari fenomena tersebut ialah agama dipahami sebagai ajaran 
rasional kemanusian yang harus diaplikasikan di ranah publik, dan masing-masing orang mempunyai tanggungjawab argumentatif yang mendasarkan pada akal sehat dan pengalaman kemanusiaan sebagai pertimbangannya (J. Rawls, 1971). Gagasan tersebut menandakan bahwa agama tidak hanya mempunyai nilai dogmatis, tetapi ada wilayah historis yang harus menjadi pertimbangan dalam mengaplikasikan nilai-nilai agama di ranah publik.

Dalam melaksanakan debat publik, ada dua hal yang harus diperhatikan, yaitu konstitusi yang demokratis yang harus konsisten dengan paham keagamaan yang beragam. Dan konstitusi demokratis harus mendapatkan afirmasi oleh para pengikut dari berbagai keyakinan keagamaan. Dua hal tersebut merupakan prakondisi untuk memastikan apakah debat publik dapat berjalan dengan baik atau tidak di parlemen. Suatu konstitusi yang tidak memuat kedua permasalahan di atas jelas bukan merupakan konstitusi demokratis.

Konstitusi demokratis juga mengidentifikasi dan mengakomodasi para partisipan dalam satu wadah untuk duduk bersama, supaya diskusi dapat berjalan dengan penuh kebebasan. Adapun prosedur untuk membuat dan mengambil keputusan, prosedur untuk melaksanakan, prosedur untuk menegakkan aturan-aturan konstitusi serta prosedur untuk mengatasi perbedaan pendapat dari para peserta harus dijelaskan dalam konstitusi. Dalam hal ini, konstitusi memberikan kebebasan dalam mengatur dan mengambil keputusan, karena konstitusi demokratis bukanlah konstitusi yang mati, dan klausul yang mewadahi penilaian yang berkelanjutan terhadap konstitusi tersebut harus juga dimuat secara jelas dalam konstitusi. Dengan demikian prosedur untuk merubah serta mengamandemen konstitusi harus secara eksplisit dimuat dalam konstitusi (Gamwell, 1995). Dalam hal ini netralitas konstitusi dipertanggungjawabkan di hadapan umum dalam mengatur dan memproduksi kebijakan yang terkait dengan kebebasan beragama.

Perdebatan dalam konstitusi memunculkan masalah baru, yaitu berkaitan dengan konsensus dalam mengambil keputusan. Problematika yang akan muncul ialah perbedaan dalam mempertahankan pendapat masing-masing dari kelompok beragama, perbedaan keyakinan atau perbedaan penafsiran akan memunculkan masalah 
konsensus. Tetapi sejauh prosedur yang digunakan mencerminkan keadilan, dalam arti bahwa prosedur tersebut tidak mendapatkan afirmasi dari berbagai kelompok keyakinan keagamaan tertentu, maka tidak ada alasan bagi kelompok yang tidak sependapat untuk keluar dan tidak mengakui keputusan-keputusan yang telah diambil. Sikap inkonsisten dan tidak mengakui atas putusan yang telah diambil dari prosedur demokratis berarti mengabaikan sikap demoratis terhadap keputusan-keputusan terdahulu yang telah ditetapkan oleh mereka sendiri (Sandel, 1984).

Problem lain dari putusan institusi ialah putusan yang telah diambil dapat berubah pada waktu tertentu, perubahan tersebut merupakan bagian dari dinamika berkonstitusi karena kebubuhan politik maupun kebutuhan sosial-keagamaan. Kelompok keagamaan tertentu pada suatu saat mungkin merasa bahwa prosedur atau tatacara dalam membuat keputusan dianggap telah memenuhi rasa keadilan dan karena mereka merasa terikat untuk patuh dan tunduk terhadapnya. Tetapi hal tersebut tidak menjamin kelompok lain merasa puas dan terikat dengan putusan yang telah diambil, karena alasan yang berbeda. Adanya berbagai perubahan situasi politik dapat merubah kebijakan dalam mengambil keputusan bagi yang merasa bahwa prosedur untuk membuat keputusan dianggpnya tidak lagi mencerminkan keadilan dan mnerubah komitmennya yang lalu.

Dalam wacana demokrasi perubahan komitmen bukan merupakan stigma buruk dan perilaku politik yang haram dilakukan. Perubahan komitmen disebabkan adanya perubahan suasana politik yang dapat dibenarkan, seperti orientasi politik yang lebih humanis. Oleh karena itu, konstitusi yang demokratis memberikan ruangan pada beberapa pemahaman baru yang menyebabkan munculnya kemungkinan-kemungkinan yang timbul akibat terjadinya perubahan komitmen tersebut. Bahkan kebebasan untuk meyakinkan orang lain untuk mencabut komitmennya terhadap prosedur yang dianggap tidak lagi mencerminkan keadilan pun harus disediakan ruangan dalam konstitusi (Gamwell, 1995). Pada wilayah ini, terdapat perdebatan untuk merubah atau mencabut pendapat yang telah ditetapkan, selain harus mendapatkan protes dari publik tentang konsistensi di wilayah pemerintahan. 
Klaim tentang keadilan secara formal mendapat tempat utama dalam demokrasi kaitannya dengan kebeasan beragama dari pada klaim material tentang keadilan. Dengan kata lain, keadilan yang bersifat prosedural harus lebih diutamakan dari pada keadilan yang bersifat material. Oleh sebab itu, permasalahan demokrasi dan kebebasan beragama pada dasarnya merupakan persoalan prosedur konstitusional yang digunakan sebagai rujukan dalam pembuatan keputusan-keputusan lainnya. Afirmasi dari seorang politikus yang mewakili agama tertentu di parlemen merupakan faktor desisif untuk memastikan bahwa klaim formal tentang keadilan telah terpenuhi. Problematika dari keadilan material ialah akan memunculkan perebutan identitas tafsir agama dalam ruang kosntitusi, sehingga mengaburkan keadilan formal. Dalam pandangan Zuli Qodir, usaha mengaplikasinya ide-ide keagamaan dalam konstitusi untuk meraih keadilan perspektif agama murni merupakan gerakan keagamaan baru yang menjadi kekuatan transformatif (Singh \& Qodir, 2015).

Konsekuensi dari beberapa fenomena perebutan otoritas keagamaan dari perdebatan keadilan secara material dan prosedural ialah mengabaikan nilai demokrasi dan lobi-lobi politik praktis. Namun hal ini bukan berarti mengesampingkan arti penting keadilan yang bersifat material. Keputusan-keputusan yang diproduk atas dasar prosedur konstitusional harus juga mendapatkan pertimbangan yang mendalam agar tetap sejalan dan tidak bertentangan dengan prosedur konstitusional secara keseluruhan. Disamping itu, nilai-nilai kemanusiaan yang ditetapkan atas dasar akal sehat juga harus menjadi bahan pertimbangan agar materi keputusan yang diproduk melalui prosedur konstitutional mencerminkan rasa keadilan. Misalnya, setelah melalui diskusi yang mendalam akhirnya parlemen menetapkan suatu peraturan perundangan yang membolehkan melakukan praktek perbudakan. Meskipun peraturan perundangan ini telah ditetapkan melalui prosedur konstitusional yang adil, peraturan tersebut tidak sejalan dengan wacana demokrasi karena pengalaman kemanusiaan serta akal sehat akan menolak praktek perbudakan untuk masa sekarang.

Keadilan bagi elemen masyarakat akan menemukan kendala serius, karena rasa keadilan antar perseorang, kelompok dengan kelompok keagamaan lainnya akan berbeda. Hal ini berkaitan dengan perspektif dan peristiwa yang melingkupi, peristiwa individual tidak bisa disamakan dengan peristiwa kelompok dalam memandang 
keadilan. Tetapi sejauh prosedur konstitusional yang termuat dalam tatacara membuat keputusan, tatacara melaksanakan, menegakkan serta merubah keputusan telah mendapatkan afirmasi sebelumnya dari berbagai kelompok keyakinan keagamaan, maka demokrasi berarti telah berjalan dengan baik. Dengan demikian, meskipun ada beberapa pihak yang tidak setuju dengan materi keputusan yang diproduk melalui prosedur konstitusional yang sudah mendapatkan afirmasi sebelumnya, tidak ada alasan bagi pihak-pihak yang tidak setuju untuk tidak patuh terhadap keputusan yang dihasilkan. Pada wilayah ini, demokrasi berjalan dengan baik bagi berbagai paham dan kelompok keagamaan di mata konstitusi.

Transparansi dan dan kebersamaan menjadi solusi dalam mengambil keputusan publik, dimana keterlibatan semua golongan dari masing-masing agama akan memberikan kontribusi dalam putusan yang akan ditentukan. Keterlibatan tersebut menambah wacana agama dalam ruang publik, sehingga kesamaan visi dan misi dalam menentukan bisa teralisasikan. Oleh sebab itu, kesadaran bersama tentang bernegara dan berdemokrasi harus dibangun atas dasar kebersamaan tanpa harus memandang agama dominan atau dominasi politik. Dengan demikian, agama tidak hanya pandang sebagai ajaran dogmatik tetapi dipahami sebagai aturan-aturan sosial yang bisa mendukung putusan dan kebijakan dalam bernegara.

\section{Demokrasi dan Formalisasi Politik Islam}

Formalisasi politik Islam berarti sebuah upaya melakukan islamisasi dalam bidang-bidang politik dengan cara mengemas konsep-konsep politik dengan kemasan Islam. Dalam bentuknya ekstrim, formalisasi Islam ditandai dengan upaya untuk melakukan islamisasi dalam setiap institusi politik yang dinyatakan secara eksplisit dan muaranya adalah pendirian negara Islam. Dalam konteks keindonesiaan, formalisasi Islam bermula dari perebutan otoritas tafsir atas ajaran agama, yaitu pengakuan atas piagam Jakarta. Geliat gerakan puritan menjadi rumit ketiak disandingkan dengan soal pemerintahan, karena berkaitan dengan perang wacana ideologi (Singh \& Qodir, 2015). Indonesia yang memegan dasar Pancasila digugat untuk menerapkan syariat Islam. Sehingga memunculkan beberapa problem rigit, yaitu bagaimana hubungan antara demokrasi, formalisasi Islam dan prinsip kebebasan beragama? Apakah logika 
demokrasi bisa bersamaan dengan gagasan formalisasi Islam, dan apakah gagasan formalisasi Islam berjalan searah dengan prinsip kebebasan beragama?

Fenomena kebangkitan gerakan formalisasi agama dalam negara berawal dari sejarah ketatanegaraan Islam pada masa awal yang dianggap sebagai model ideal untuk menyatukan agama dan negara. Nabi Muhammad sebagai manusia ideal dianggap berhasil dalam menjadikan Madinah sebagai pusat peradaban Islam dan negara, sehingga memicu semangat untuk mengembalikan kejayaan Islam di era modern. Formalisasi agama menandakan kebangkitan gerakan Islam puritan dalam pemerintahan, tetapi hal ini hanya sebagian faktor perebutan otoritas kegamaan dalam konstitusi. Preseden ini yang membangkitkan romantisme sebagian umat Islam untuk melakukan formalisasi Islam, meskipun secara politik dan sosial terdapat perbedaan signifikan.

Kelompok formalisasi Islam mempunyai empat argumentasi dalam menghidupkan kembali politik Islam. Pertama, menyangkut prinsip kedaulatan. Dalam ajaran Islam kedaulatan berada di Tangan Tuhan. Oleh karena itu para penguasa dalam mengatur negara tidak boleh hanya berdasar pada keinginan rakyat tetapi mereka harus bertindak atas nama Tuhan. Tugas utama para penguasa hanyalah melaksanakan apa yang telah diperintahkan oleh Allah dalam al-Quran. Karena kepatuhan itu pada dasarnya hanya kepada Tuhan, tidak ada ruang bagi nasionalisme dalam politik Islam (Maududi, 1983) dan (Rauf, 1993). Kedua adalah konsep tentang musyawarah. Dalam politik Islam institusi musyawarah menjadi praktek kenegaraan yang dilakukan sejak zaman Nabi sampai pada zaman khalifah Ali. Institusi musyawarah berhenti beroperasi ketika terjadi perubahan bentuk pemerintahan Islam dari sistem khilafah menjadi sistem kerajaan. Ketiga, negara Islam harus kometmen terhadap pelaksanaan syariah. Dan keempat, negara Islam menganut asas kesamaan hak bagi seluruh warga negara. Baik muslim maupun non-muslim memiliki harga darah yang sama. Ajaran tersebut terdapat dalam al-Quran, jika seorang muslim membunuh seorang non-muslim, pembunuh yang muslim tersebut berhak mendapatkan hukuman mati (Rauf, 1993).

Kasus hukum yang menyangkut kriminal maupun perdata, semua warga negara tanpa perbedaan latar belakang, keyakinan, ras dan identitas memiliki hak dan 
kewajiban yang sama di depan hukum. Dengan bahasa lain, warga negara mempunyai kewajiban mengayomi dan menindak warganya yang melanggar hukum, dan tidak ditentukan dari agama, golongan dan lain sebagainya, seperti warga non-muslim memiliki hak untuk ambil bagian dalam kegiatan pelayanan negara. Dalam hal ini, warga ikut berperan dalam memajukan negara. Sebagaimana warga muslim, warga nonmuslim harus diberikan kepercayaan untuk menduduki dan menempati kantor pelayanan umum serta terlibat dalam kegiatan militer. Warga non-muslim tidak boleh mengalami penderitaan akibat diskriminasi yang dilakukan oleh para penguasa muslim (Rauf, 1993). Oleh sebab itu, ada jalinan intensif antar agama yang bersama membangun negara.

Dalam negara Islam, warga non-muslim memiliki hak untuk melaksanakan ajaran serta keyakinan keagamaan selama tidak membahayakan kepentingan umum. Mereka juga dibebaskan dari peraturan-peraturan yang dikhususkan bagi warga muslim. Oleh karena itu, mereka bebas mengkonsumsi minuman keras maupun daging babi selama dalam pengkonsumsian itu tidak ada pihak-pihak yang dirugikan (Rauf, 1993). Dalam dogma Islam, memandang non-muslim demikian disebut sebagai kafir zimi, yaitu warga non-muslim yang ditanggung oleh negara Islam dalam menjalankan ibadah dan kehidupan, tetapi harus membayar pajak untuk kehidupan. Menjamin keagamaan warga non-muslim dalam Islam diajarkan, tetapi dengan berbagai persyaratan, termasuk tidak bisa mengganggu kehidupan umat Islam, membayar pajak dan bersikap adil.

Gagasan tentang kesamaan hak dan kewajiban bagi muslim dan non-muslim adalah ajaran ideal dalam Islam. Oleh sebab itu, tidak ada halangan untuk mengaplikasikan ajaran Islam dalam tatanan politik dalam rangka formalisasi Islam. Tetapi problematika yang muncul ialah efektifitas, keadilan, dan kesetaraan karena dogma agama secara tekstual tidak secara menyeluruh menjelaskan tentang aturan bertatanegara, hanya bagian kecil yang menjelaskan untuk mendukung keberlansungan hidup bersama. Penerapan syariah di ranah publik dan pengaturan secara syariah di ranah publik tanpa harus dipahami dan diinterpretasikan ulang akan meruntuhkan norma sosial dan budaya, karena produk keagamaan tercipta dari problem sosial yang harus disadari. Begitu juga dengan dogma-dogma kenegaraan yang terdapat dalam 
sumber-sumber otoritatif. Sehingga penerapan ajaran Islam dapat disesuaikan dengan kondisi sosial yang bersumber dari pemahaman terkonstruktur.

Problem lain dari formalisasi agama Islam dalam perundang-undangan negara berdampak pada hilangnya hak dan kewenangan agama lain dalam kehidupan bernegara, karena tidak mempunyai ruang dalam menghayati ajaran yang berbentuk formal. Pada saat yang sama, eksistensi manusia sebagai makhluk yang utuh harus dibatasi dengan aturan-aturana agama. Meskipun secara teologis agama tidak dipandang sebagai ajaran yang absolut, dan harus diperdebatkan dalam wilayah publik. Karena hal tersebut tidak bisa dipisahkan dari watak asli agama. Dalam hal ini agama mengalami anomali yang sampai pada krisis interpretasi dan aplikasi. Anomali yang dialami oleh agama adalah ranah interpretasi keyakinan beragama dijamin dan dilindungi, sehingga warga non-muslim mempunyai kesamaan hak (dalam kehidupan sosial) dan wewenang dalam menentukan kehidupannya. Tetapi secara aplikatif norma agama telah membatasi manusia sebagai makhluk independen dengan ajaran agama. Sehingga agama menggambarkan dua wajah dalam satu putusan.

Meyakini kedaulatan Tuhan dalam konstitusi akan menghilangkan logika manusia, karena menempatkan kedaulatan Tuhan jelas akan mengkaburkan wilayah politik dan agama, karena tidak ada batas yang jelas dan tidak mencerminkan kegiatan politik murni. Kedaulatan Tuhan hanya ada dalam agama, adapun perpolitikan merupakan wilayah manusia yang tidak ada ajaran dalam agama. Adapun nilai agama di dalam yang dianut, hal tersebut bagian dari pemahaman yang sama. Meskipun dalam ajaran agama, para pemimpin Islam harus selalu menjaga amanat Allah, dan bahwa mereka akan dimintai pertanggung-jawaban oleh Allah nanti di akhirat, itu adalah persoalan lain yang tidak harus disebutkan dalam konstitusi. Sebagai muslim yang harus menyadari bahwa masalah kepemimpinan, serta kegiatan-kegiatan politik lainnya tidak dipandang sebagai urusan politik yang bersifat duniawi belaka. Ini berarti mengisyaratkan bahwa seorang muslim yang baik dapat membedakan antara gerakan politik dan kegiatan agama dalam ruang sosial.

Wilayah otoritatif menjadi problem rigit dalam menentukan konteks kewenangan dalam bernegara dan beragama. Dalam hal ini, komunitas interpretasi 
mempunyai pengaruh besar dalam menentukan putusan keagamaan, karena sumber otoritatif pada suatu waktu dimanupulasi oleh kelompok tertentu dalam penafsirannya (Muhtador, 2012, hal. 21). Sehingga memunculkan tafsir-tafsir otoriter pada waktu tertentu memenangkan salah satu tafsir. Begitu juga dengan penafsiran tentang relasi agama dan negara yang terkadang tidak seimbang. Pada wilayah ini, keterpengaruhan dalam tafsir menjadi sumber bencana bagi negara karena menimbulkan paham otoritarianisme.

Wacana demokrasi, negara tidak dibenarkan mendukung keyakinan tertentu secara menyeluruh. Dengan bahasa sederhana, negara tidak boleh berpihak pada agama tertentu dalam membuat kebijakan publik, karena menimbulkan konflik horisontal. Dengan demikian, setiap keyakinan harus menjadi bagian dari negara dan kebijakan yang diambil memberikan keadilan pada setiap warga negara. Adapun kebijakan yang tidak mencerminkan nilai demokrasi harus direvisi, karena demokrasi tidak mengenal agama dan identitas warga (Gamwell, 1995). Di dunia modern dengan mudah kita akan menemukan superioritas agama dalam negara, misal Negara Islam Pakistan atau Republik Islam Iran, secara prinsip negara tersebut menafikan unsur-unsur demokrasi. Karena negara hanya mengakomodir satu agama dalam kebijakan politik, hal demikian ini jelas tidak memenuhi keadilan formal atau keadilan prosedural.

Meminjam kritik Abdullah Soroush terkait kasus kuasa agama atas negara di Iran ialah konstruksi ketidakadilan bersumber dari tidak adanya pemisah secara interpretasi antara ajaran agama dan interpretasi agama, dampak serius ialah etika etika negatif (unethical), seperti asumsi ketertutupan pintu ijtihad sehingga tidak bisa menciptakan hukum baru dalam kehidupan bermasyarakat dari problem yang mengitari, hal ini dadalah bentuk tafsir otoriter. Asumsi tersebut telah menyingkirkan akal manusia sebagai media utama dan manusia yang dibedakan dengan makhluk lain. Menghilangkan peran akal berdampak pada hilangnya kritisisme berpikir dan stagnasi pemikiran agama. Pada wilayah yang sama, munculnya gerakan sufi yang menitik beratkan pada gerakan ritual memudarkan pemikiran pemikiran filsafat, hukum, dan sejarah Islam. Akumulasi negatif tersebut berdampak pada perpecahan para ulama yang disebabkan adanya perbedaan pandangan tentang agama, karena adanya kecenderungan tafsir agama dan terbentuknya aliansi ulama yaitu agama versi 
pemerintah (governments religion) dan agama versi rakyat (peoples religion) (Soroush, 2000).Lalu di mana letak kebebasan beragama dalam negara yang secara eksplisit menyatakan dukunyannya terhadap suatu keyakinan keagamaan tertentu?

Beberapa asumsi yang disalah artikan ialah ketika negara tidak mengakomodasi seluruh keyakinan masyarakat, tetapi hal tersebut tidak berarti mendiskriminasi agama tertentu atas kebijakan yang telah diambil, Dalam prakteknya negara yang hanya meyakini ajaran tertentu juga memberikan ruang kebebasan sosial pada seluruh agama, tetapi dengan batas tertentu yang bisa mendukung keberlangsungan negara, salah satu contohnya ialah Iran. Meskipun Iran tetap menerapkan sistem keagamaan dalam bernegara bukan berarti Iran mendiskriminasi agama yang tidak sesuai dengan putusan negara. Hal tersebut bisa dibandingkan dengan di Indonesia. Kehidupan bernegara di Iran mungkin lebih baik daripada Indonesia yang secara jelas tidak mendukung salah satu keyakinan keagamaan tertentu. Namun satu hal yang perlu dipertimbangkan dalam wacana demokrasi bahwa jaminan keadilan yang bersifat prosedural lebih bermakna daripada keadilan yang bersifat material. Atas dasar prinsip keadilan prosedural dapat dikatakan bahwa negara Islam lebih menjanjikan materi keadilan dibandingkan keadilan proseduran, namun prinsip demokrasi harus memenuhi keadilan prosedural (Toros, 2010).

Berkomitmen untuk mematuhi syariah merupakan keharusan bagi setiap muslim. Akan tetapi prinsip demokrasi jelas akan menolak jika syariah secara eksplisit dijadikan sebagai tata hukum bagi negara tertentu, karena syariah dan prinsip demokrasi tidak menemukan titik temu. Dan hal tersebut tidak berarti menafikan arti penting syariah bagi pengamalnya. Tetapi dalam prakteknya, suatu negara menerima banyak masukan peraturan perundangan yang berasal dari syariah, misalnya hukum qisas atau had bagi pengkonsumsi minuman keras dan lain-lainnya. Sudah barang tentu aturan syariah itu masuk menjadi perundang-undangan negara setelah melalui proses diskusi dan debat publik yang mencerminkan keadilan prosedural. Berkat usaha dari para wakil rakyat yang muslim, akhirnya berhasil meyakinkan anggota parlemen lainnya sehingga banyak aturan syariah yang diterima menjadi hukum pidana dan perdata. Akan tetapi jika negara menerima berbagai ketentuan syariah menjadi hukum pidana dan perdata, hal ini semata-mata hanya karena peran politikus agama yang mewakili di meparlemen dengan berbagai pertimbangan rasional. Adanya hukum 
syariah sebagai aturan negara tidak berarti menjadikan negara agama. Dengan demikian, secara eksplisit negara harus menyatakan bahwa apa yang dilakukannya merupakan kegiatan politik, adapun pengadopsian syariah yang berhasil dilakukannya pun tidak boleh diklaim sebagai kegiatan keagamaan. Secara implisit negara boleh saja mengklaim bahwa apa yang dilakukannya merupakan tugas suci keagamaan, namun hal tersebut harus dinyatakan sebagai kegiatan politik dan ditujukan untuk menjawab pertanyaan yang bersifat partial, bukan pertanyaan yang bersifat komprehensif.

Dalam melakukan debat publik di parlemen, masing-masing kelompok keagamaan diperbolehkan untuk merujuk kepada apa yang menjadi pemahaman agama atau dipersilahkan merujuk pada al-Qur'an, Sunnah Nabi serta sumber-sumber lainnya yang dianggap otoritatif. Sama halnya, kelompok Kristen diperbolehkan untuk merujuk pada kitab-kitab kanonikal dan sumber-sumber otoritatif lainnya untuk mendukung pendapatnya. Kelompok Budha juga dibenarkan untuk menggunakan Tri Pitaka sebagai sumber rujukan, bahkan kelompok ateis pun dipersilahkan untuk menggunakan logika serta etika sekular untuk mendukung argumennya. Pendek kata, dalam wacana demokrasi setiap kelompok atau setiap orang bebas untuk mengemukakan gagasannya dengan menggunakan dukungan keagamaan yang diyakininya sebagai alat pembenarnya. Hal ini berbeda dengan prinsip free-standing justice dari John Rawls yang hanya menghendaki pembenaran dari ide-ide yang secara implisit hidup dalam budaya politik (John Rawls, 1993). Dengan demikian Rawls menganggap bahwa keyakinan keagamaan sama sekali tidak memiliki arti penting dalam kehidupan politik. Keyakinan keagamaan harus dikesampingkan ketika seseorang bermain dalam arena politik.

Meskipun syariah telah menjadi elemen utama dalam sistem perundangan suatu negara, negara harus tetap menjaga netralitasnya. Negara tidak boleh beranggapan bahwa ketentuan syariah yang diadopsinya diperuntukan bagi kelompok keagamaan tertentu atau jawaban atas pertanyaan yang sifatnya agamis. Ketika syariah telah diadopsi menjadi hukum positif, fungsinya menjadi berubah. Syariah yang semula dianggap sebagai jawaban atas pertanyaan yang agama, berubah menjadi kebijakan negara yang harus mengakomodasi kepentingan masyarakat umum dan karenanya telah masuk dalam lingkup kegiatan politik. Untuk itu, tidak dibenarkan memberlakukan syariah yang telah berubah menjadi hukum positif tersebut untuk menjawab pertanyaan 
yang sifatnya komprehensif. Pada wilayah ini syariah atau paham keagamaan tidak bisa dipahami sebagai aturan agama secara formal, ketika masuk dalam ranah politik.

Meskipun pada dasarnya, agama dan negara saling menguatkan satu sama lainnyay. Namun hal yang harus diperhatikan ialah sejauhmana efektifitas tafsir atau paham agama dapat diformalisasikan ke dalam negara. Karena tafsir agama bersumber dari problem sosial yang melingkupi penafsirnya yang pada akhirnya akan memunculkan perspektif baru yang terus berkembang. Dengan demikian, pembacaan agama dan negara harus dipahami sebagai relasi produktif yang menilai keduanya saling menguatkan dalam mengatur kehidupan masyarakat.

\section{Simpulan}

Permasalahan yang berhubungan dengan kebebasan beragama dalam ranah publik merupakan suatu diskursus politik yang hanya bisa dilaksanakan secara baik dengan pendekatan demokratis dan ada dua model yang bisa ditawarkan dalam hal ini. Pertama, model pendekatan demokratis seperti yang dikemukakan oleh Gamwell merupakan cara yang tepat untuk mengatasi problematika politik modern yang berkaitan dengan kebebasan beragama. Hal ini didasarkan atas dua alasan. Pertama, model pendekatan demokratis yang dikemukakannya sangat mengedepankan arti penting otentisitas serta keutuhan manusia sebagai subjek yang memainkan dua peran sekaligus, yakni peran sebagai manusia politik dan peran sebagai manusia agamis. Kemampuan dalam memadukan dua peran inilah yang membuat model pendekatan Gamwell menjadi sangat padu dan tepat untuk mengatasi problematika politik modern yang berkenaan dengan persoalan kebebasan beragama. Kedua, keunggulan model pendekatan Gamwell terletak dari penekanannya terhadap prinsip procedural justice. Hal inilah yang membuat pendekatan demokratis yang dikembangkannya akan mampu meredam konflik politik horisontal karena masing-masing kelompok pendukung keyakinan keagamaan baik dari kalangan mayoritas maupun kalangan minoritas akan merasa terayomi dengan adanya jaminan prosedur konstitusional.

Model yang digagas John Rawls berangkat dari tesis bahwa agama adalah persoalan pribadi yang tidak mempunyai kaitan dengan ranah publik, yang biasa disebut dengan pendekatan liberal-privatist. Model ini tidak memberikan tawaran pada 
problem kemanusiaan karena menempatkan manusia dalam posisi split personality atau tidak bersifat dwifungsi, manusia dianggap sebagai manusia agama yang patuh pada doktrin keagamaanya tanpa harus melebur pada negara. Pada saat berbeda, seorang dianggap menjadi politikus yang tidak dapat membawa ajaran agama dalam ranah publik. Gagasan ini menjadi lemah karena melupakan ontologi manusia sebagai makhluk bebas yang dapat merubah sikap, gagasan dan perilaku pada saat bersamaan. 


\section{Referensi}

Anwar, S. (1998). Metodologi Penelitian. Yogyakarta: Pustaka Pelajar.

Audi, R., \& Wolterstorff, N. (1977). Religion on teh Public Square, The Place of Religious Conviction in Political Debate. Boston: Rowman \& Littlefield Publisher.

El. Wa, M. (1983). Sistem Politik dalam Islam (Terj.). Surabaya: Bina Ilmu.

Gamwell, F. I. (1995). The Meaning of Religious Freedom, Modern Politics and the Democratic Resolution. Albany: State University of New York Press.

Gray, J. (1991). Liberalisms, Essayas in Political Philosophy. London: Routledge.

Gray, J. (1993). Post Liberalism, Studies in Political Thought. London: Routledge.

Greevawalt, K. (1988). Religious Convictions and Political Choice. Oxford: Oxford University.

Hadi, S. (1983). Metodologi Research. Yogyakarta: UGM Press.

Haryatmoko. (1998). Telaah Historis Negara Kesejahteraan. Journal Tashwirul Afkar, (3).

Haynes, J. (1993). Religion in Third World Politics. Buckingham: Open University Press.

Kholiludin, T. (2009). Kuasa Negara atas Agama. Semarang: ReSAIL.

Koshy, N. (1992). Religious Freedom in a Changing World. Geneva: World Council of Churches.

Maududi, A. 'Ala. (1983). Dasar-dasar Konstitusi Islam. Bandung: Mizan.

Mclver, R. (1950). The Modern State. London: Oxford University.

Moleong, L. J. (1989). Metodologi Penelitan Kualitatif. Bandung: Remaja Rosda Karya.

Muhtador, M. (2012). OtoritasTeks Sunah dan Problem Otoritarianisme (Sudi Pemikiran Khaled M. Abou El-Fadl). STAIN Kudus.

Rauf, M. A. (1993). The Concept of Islamic State with Particular Reference to Treatment of Non-Muslim Citizens. Kuala Lumpur: Islamic Affairs Division Primer Minister's Departement. 
Rawls, J. (1971). A Theory of Justice. Cambridge: Harvard University.

Rawls, J. (1993). Political Liberalism. New York: Columbia University Press.

Sandel, M. (1984). Liberalism and Its Critics. New York: Blackwell Publishing.

Singh, B., \& Qodir, Z. (2015). Gerakan Islam non Mainstream dan Kebangkitan Islam Politik di Indonesia. Yogyakarta: Pustaka Pelajar.

Soroush, A. K. (2000). Reason, Freedom and Democracy in Islam. New York: Oxford University.

Sugiyono. (2005). Memahami Penelitian Kualitatif. Bandung: Alfath Offset.

Toros, E. (2010). The Relationship Between Islam and Democracy in Turkey: Employing Political Culture as an Indicator. Social Indicators Research, 95(2), 253-265. http://doi.org/10.1007/s11205-009-9458-1 